\title{
Are high school teachers and university academics on the same page? A case of the university readiness of business education learners at two schools and two universities
}

\section{Karen dos Reis}

Teaching and Learning Unit, Faculty of Economic and Management Sciences, University of the Western Cape, Cape Town, South Africa

kdosreis@uwc.ac.za

https://orcid.org/0000-0003-4625-6004

\section{Antoinette Venter}

Directorate: Curriculum GET, Western Cape Education Department, Cape Town, South Africa Antoinette.Venter@westerncape.gov.za https://orcid.org/0000-0001-7834-4418

\section{Venicia McGhie}

Department of Academic Development, Faculty of Economic and Management Sciences, University of the Western Cape, Cape Town, South Africa

vfmcghie@uwc.ac.za

https://orcid.org/0000-0003-0581-3089

(Received: 17 February 2019; accepted: 2 August 2019)

\section{Abstract}

Many studies nationally and internationally continue to find that schools are not preparing learners adequately to cope with the demands of higher education, hence the high dropout rate particularly at the first-year level. We found that, in most cases, research studies conducted in South Africa focus solely on a particular stakeholder's perception to gain insights into students' readiness for university as opposed to corroborating perceptions of both teachers and academics. Thus, the aim of our paper is to explore the perceptions of both business education high school educators and lecturers in terms of how they view the readiness of learners for university, particularly for the bachelor of commerce degree programme. The findings highlight the lack of communication and collaboration between schools and universities. Recommendations are proposed to assist the staff of high schools and universities to work collaboratively in order to provide high school learners with adequate foundational knowledge and skills that will ensure that they are ready for higher education studies. We argue that exploring the perceptions of high school teachers and academics collectively could be a step in the right direction towards paving the way for successful learning at university for first-year students in bachelor of commerce degree programmes.

Keywords: learners, teachers, high school, business education, readiness, higher education, academics, successful learning 


\section{Introduction and background}

The end of apartheid earmarked a new and exciting beginning for democracy in South Africa. The previously fragmented departments of education were demolished, and a new national Department of Education was constituted, with three bands: the General Education and Training band; the Further Education and Training band; and the Higher Education and Training band (Department of Education, 1998). However, as a consequence of apartheid, the national Department of Education inherited an unequal and poorly resourced education system in which most public schools do not equip the learners with the necessary skills and knowledge needed to succeed in higher education (Rantsi, 2016; Spaull, 2013).

Given the context of the South Africa's unequal education system, not all learners are adequately prepared for tertiary education because at school there is a discrepancy between the skills and knowledge that students gain in high school versus the skills and knowledge required by higher education institutions. The Diagnostic Report of the Department of Basic Education (2016) highlights areas of concern in the National Senior Certificate Examination. These include Grade 12 learners' "lack of independent or creative thought, their inability to cope with analytical, evaluative and problem-solving type questions" (Department of Basic Education, 2016(a), p. 7) and the poor language skills of a vast majority of those who sat for the examinations. These are the skills (in addition to subject-specific knowledge) that higher education institutions require prospective students to have when they are admitted to a diploma or degree programme.

It is against this backdrop that in this paper we report on one part of a larger study conducted at two high schools in Western Cape Province. The focus of the larger study was on the Business Education Learning Area that is offered to Grades 10, 11, and 12 learners (referred to as the Further Education and Training Phase). The research participants were learners, subject advisers, the teachers responsible for teaching the three subjects (accounting, economics and business studies), and academics at two universities who were responsible for teaching first-year students in their business faculty. Here, we consider the views and perceptions of the teachers and academic participants regarding the readiness of business education learners for post-school studies.

We begin with a review of relevant literature on the South African public schooling context, followed by a discussion of the higher education context. Thereafter, we discuss the theoretical underpinnings of the paper and this is followed by an explanation of the methodological processes, and a summary of the results. We conclude the paper with a discussion of the findings, and suggestions on how teachers and academics could work collaboratively to equip business education learners with the knowledge and skills needed to succeed at university level. 


\section{South African Schooling: A tumultuous context?}

In 2015, the Organisation for Economic Co-operation and Development (OECD) ranked the South African education system in the bottom two out of the 76 countries on which the organisation reported (Nonjinge, 2018). The South African Child Gauge revealed that a staggering $58 \%$ of children cannot read fluently and with comprehension at the end of Grade 4 (Nonjinge, 2018). Out of 100 learners who start school, approximately 60 will reach and write matric, 37 will pass, and 12 will access university. Only 4 will complete an undergraduate degree within 6 years. Low through-put rates and weak performance in high school is rooted in weak foundations from primary school (Spaull \& Kotze, 2015).

Moreover, Letseka (2014) has explained that because many public schools in South Africa are dysfunctional, this has a bad effect on the learners since they do not develop the necessary skills and qualities to read effectively and do well in mathematics. Consequently, the failing and repeating rates in schools, especially in Grade 10 is high (Department of Basic Education, 2016(b); Letseka, 2014).

In addition to these grim statistics regarding low literacy and numeracy skills, South Africa is also experiencing a shortage of teachers. The country will be in need of as many as 30, 000 additional teachers by 2025 (World Education News \& Reviews (WENR), 2017). What is further concerning is that some of the current teachers do not have the basic pedagogic and content knowledge competencies needed to facilitate learning for the learners while teacher late-coming, absenteeism, and an inability to enact the basic functions of teaching are endemic in many public South African schools (Department of Basic Education, 2016(a); Letseka, 2014). Modisaotsile (2012) has also included poor teacher-training, as well as unqualified and demotivated teachers as part of the ongoing challenges in the South African schooling system.

Furthermore, the constant shift in South Africa's educational curriculum reforms remains challenging in some respects. For example, there are problems with content overload and curriculum coverage, and with the poor quality of formal assessment tasks along with challenges relating to understanding how to use cognitive levels, different forms of assessment, the weighting of assessment with regard to time and marks, and the development of 21st-century skills (Maboya, 2017). Sharing a similar sentiment, Goetze (2016) has stated that the most recent curriculum reform, Curriculum Assessment Policy Statements (CAPS), is disadvantaging learners because it is too content-heavy and does not allow for consolidation time, has a rigid approach, includes the over-assessment of learners, and does not develop critical thinking skills in them. Because of these disadvantages, learners exit the public high school system without achieving the desired outcomes or being the envisaged learners that CAPS hoped to produce (Rantsi, 2016). Consequently, the social demand for better schools, effective principals, qualified and committed teachers, and better opportunities for all poses a huge challenge to provinces and to the state to protect the rights of all citizens (Department of Basic Education, 2016(b)). 


\section{South African Higher Education: An intricate system?}

The historically unequal distribution of economic, social, and cultural capital in South Africa has created disparities in the manner in which first-year students adjust and succeed at university. According to Morrow (2009), research into student access to higher education has illustrated that such access does not necessarily ensure significant academic and social engagement and retention, nor successful learning. This fact lies behind South Africa's pressing need for more skilled graduates to take forward all forms of social and economic development (Council of Higher Education, 2013). The quantity and quality of the country's graduate outcomes have major implications for social, political, and economic development, particularly in a context of a scarcity of skills. To this end, Leibowitz, van der Merwe, and van Schalkwyk (2009) have explained that the number and worth of South Africa's graduate outcomes could have severe implications for the growth and development of the economy, specifically regarding relation to scare skills' occupations.

In addition, higher education has become more complex, given the increase in student numbers, including what are known as non-traditional students, for example, first-generation entrants, mature students, and students from disadvantaged communities (Council of Higher Education, 2013, 2016). The last few decades have seen the introduction, on a large scale, of bridging and foundational programmes, student support programmes, more career guidance and counselling, different pedagogies, more explicit and transparent expectations and criteria for assessment, and a much wider range of modes of delivery facilitated by the developments in information and communications technology (Council on Higher Education, 2013, 2016). In 2014, there were 26 public universities in South Africa consisting of 14 traditional research universities, six universities of technology, and six comprehensive universities (Department of Higher Education and Training, 2016). For 2018, a total of 1, 060, 312 students were projected to enrol in public universities with 208, 308 of them being first-time entering students (Department of Higher Education and Training, 2016).

Despite the increase in enrolments for African and coloured students, there is still a huge disparity between the learners who passed with a bachelor pass and the ones who register at a university, compared to the overall population statistics (Statistics South Africa, 2019). For example, in 2017, 35.3\% of white students attended a post-school institution, followed by Asian students at $27.1 \%$, while only $10.2 \%$ of African students, and $8.2 \%$ of coloured students attended a post-school institution (Statistics South Africa, 2019). This means that $65.3 \%$ of African and $81.5 \%$ of coloured young people between the ages of 18 and 24 were not attending an institution of higher learning in 2017 (Statistics South Africa, 2019).

Moreover, from the cohort of students who enrolled in 2011, an average of 29\% completed their degree programmes in the prescribed period of three years (by the end of 2013). Another $29 \%$ took three more years to complete, while the remaining $42 \%$ dropped out, with the largest portion of dropouts occurring in the first year of study (Council on Higher Education, 2016). More specifically, for Black students who access higher education, 20\% complete their degree in the prescribed time, $30 \%$ take a further 2 to 3 years to finish, and 
$50 \%$ drop out before obtaining their qualifications (Council on Higher Education, 2013). Thus, the higher education landscape in South Africa is still characterised by a high-attrition and a low throughput rate (Fisher \& Scott, 2011).

The alarming statistics above direct attention to the fact that learners who are doing business education subjects (accounting, economics and business studies) at high school should be supported and equipped with a solid foundation and knowledge base so that their chances of succeeding at university or college will be strengthened. A recent study conducted in South Africa found that there was a correlation between a high mark achieved in accounting at school and the mark achieved in accounting 1 at university (Papageorgiou \& Halabi, 2014). Similarly, an Australian study confirmed that accounting as a school subject is beneficial for studying, in particular, first year tertiary accounting (Alcock, Cockcroft, \& Finn, 2008). This study highlighted that studying accounting at school appears to be specific only to studying the accounting module at tertiary level. They also found that the curriculum of the accounting done at school was aligned with the curriculum of an introductory accounting module at university, hence, the correlation was expected. Rankin, Silvester, Vallely, and Wyatt (2003) were also of the view that prior high school accounting knowledge influences students' academic performance in accounting modules at university.

However, in the case of economics, students who did not do economics as a school subject can successfully pass economics at university level provided there is an intervention programme to support them. Dos Reis and Yu (2018) who conducted a study on an economics' peer mentoring intervention to provide support to first-year students who did not enrol for economics in Grade 12, highlighted this finding. The peer mentoring intervention provided extra tutorial support to bachelor of commerce students who were registered for a four-year degree programme. The intervention was successful in that the students who were part of the peer mentoring intervention outperformed those who were not mentees in both the formative and the summative assessments. Thus, this finding provides evidence that learners who do not have economics as part of the business education subjects at school, could be successful at economics 1 at university level through the provision of academic support (Dos Reis \& Yu, 2018).

The same inference could be made for business studies, which correlates to management 1 at university level. During the first semester of 2017, a language support programme among all the first-year modules was introduced in the business faculty at the University of the Western Cape. The aim of the support programme was to strengthen the first-year students' chances of passing all their first semester modules. The results showed that the highest pass rate was achieved in the management 1 module, despite the fact that more than 50\% of the students did not do business studies at high school (Dos Reis, 2017).

The success of students in economics and business studies at university level, despite the fact that they did not do these subjects at high school level, draws attention to the provision of epistemological access (Morrow, 2009). Morrow had advocated that widening university access to formally disadvantaged students has to do, on the one hand, with formal access, which refers to making it possible for students to be accepted into a degree or diploma 
programme. Epistemological access, on the other hand, he argues, has to do with the provision of foundational knowledge and skills that will enable students to succeed academically. Lewin and Mawoyo (2014, p. 56) define epistemological access "as the extent to which students are able to and enabled to access the academic workings and expectations of university study, also described as 'scaffolding' and the 'discourses of learning"'. We suggest that higher education institutions are experiencing high attrition and a low throughput rate because they do not ensure epistemological access to the students they admit. This means that there should be closer liaison and cooperation between high schools and higher education in order to ensure that Grade 12 learners are equipped with the foundational knowledge and skills that will prepare them for post-school studies. This is our goal of this paper; we report on the views and perceptions of high school teachers and university lecturers with regard to the readiness of learners for post-school studies in business faculties. The objective is to arrive at recommendations that could be implemented by both high schools and post-school institutions to prepare high school learners for further education and training.

\section{Theoretical framework}

It is imperative that first-year students are academically ready for post-school studies, given the discussion in the previous sections and the pass and dropout statistics provided. Byrd and MacDonald (2005) and Conley (2007) have stated that readiness for university education is predominantly associated with high school academic achievement and results of admission tests. After a review of literature on readiness theories in South Africa, Lemmens's (2010) readiness and retention model was deemed suitable as the theoretical framework for this paper. This model focussed on the readiness characteristics that South African students present upon entering the university, and the contextual or environmental dimensions in which the readiness characteristics are located. Lemmens based his readiness theory on the work of Conley (2007). He identified four dimensions of readiness characteristics:

- Contextual dimension (parental, socio-cultural and financial);

- Cognitive sub-dimension (skills and abilities, and academic preparedness);

- Non-cognitive sub-dimension (educational values, self-efficacy, target goal, beliefs and behaviours, and coping strategies); and

- Biological dimension (gender and race) (Lemmens, 2010, p. 279).

The overall readiness characteristics of Lemmens's model are "high school achievement, race, language, credits registered for, goal orientation, learning-efficacy, gender, distance from school, reading behaviour, parental education, study choice, distance of parental home, and financial pressure on the student to pay for studies and living costs" (2010, p. 279). His main findings revealed that the readiness characteristics of students show a direct relationship with academic success and intention to withdraw. Following Conley (2007), Lemmens has acknowledged that transition to university or college includes not only key content knowledge, but also cognitive strategies, learning skills and techniques, and knowledge and skills related to the transition to higher education institutions. This implies that high school learners should not be taught only cognitive knowledge, but also soft skills and other 
attributes that would lay the foundation on which lecturers could build and thus strengthen students' chances of success in higher education. It is also important to note that the four dimensions are interdependent and related, and that, when one or more of these dimensions prove problematic, it could lead to failure and dropout for students (Conley, 2007; Lemmens, 2010). For the purposes of our study and this paper, three of the four dimensions (contextual dimension, cognitive sub-dimension, and non-cognitive sub-dimension) of Lemmens's readiness and retention model were used as the basis for the analysis of the data, and the discussion and interpretation of the findings.

\section{Research methodology and design}

The larger study was situated in a qualitative, interpretive research paradigm. Qualitative research, according to Henning, Hutter, and Bailey (2011), allows a researcher to scrutinise the experiences of people in their natural environment in order to identify how their experiences and behaviours are formed by the societal, financial, traditional, and daily contexts in which they live. Our intention in this paper is to present what the teachers do to prepare the learners for post-school studies. We then present what academics at universities think of this and conclude whether they think that the learners were adequately prepared, or not, for tertiary studies.

Following Creswell (2014), we agree that qualitative research allows for purposefully selected participants and sites that will assist us as researchers to understand the problem and the research question. Our research sites included two high schools and two universities in Western Cape Province. Learners at a Quintile 1 (no fee paying) high school in a semi-rural community and a Quintile 4 (fee paying) high school situated in an urban community participated in this study. There were four different research participants in the larger study, thirty learners from each of the two schools (60 in total), three teachers from each school (6 in total), the FET Phase subject advisers ( 3 in total), and three academics from each of the two universities (6 in total).

Semi-structured interviews were conducted with the teachers and the lecturers. Two teachers (one from each school) were teaching accounting, two were teaching business studies, and two were teaching economics at the two high schools. Similarly, two academics (again, one from each university) were responsible for teaching accounting, two for teaching economics, and two for teaching management at the two universities. One university was a traditional university, and the other was a university of technology. Numbers and initials have been used as pseudonyms for ethical reasons. Tables 1 and 2 below reflect the subjects and years of experience of the teachers and the academics as well as the numbers allocated to interviews with them. 
Table 1: Interview numbers, pseudonyms of teachers, their subject, and years of experience

\begin{tabular}{|l|l|l|l|}
\hline $\begin{array}{l}\text { Semi-structured } \\
\text { Interviews }\end{array}$ & Pseudonyms & Subject & Years of experience \\
\hline Number 1 & AB & economics & 1 year \\
\hline Number 2 & MN & economics & 31 years \\
\hline Number 3 & AH & accounting & 27 years \\
\hline Number 4 & TK & accounting & 4 years \\
\hline Number 5 & MJ & business studies & 16 years \\
\hline Number 6 & NS & business studies & 9 years \\
\hline
\end{tabular}

Table 2: Interview numbers, pseudonyms of lecturers, their discipline/subject, and years of experience

\begin{tabular}{|l|l|l|l|}
\hline $\begin{array}{l}\text { Semi-structured } \\
\text { Interviews }\end{array}$ & Pseudonyms & Discipline/subject & Years of experience \\
\hline Number 1 & VG & business management & 11 \\
\hline Number 2 & MM & & 21 \\
\hline Number 3 & BW & financial accounting & 5 \\
\hline Number 4 & LB & financial accounting & 7 \\
\hline Number 5 & NH & entrepreneurship & 2 \\
\hline Number 6 & WD & financial accounting & 8 \\
\hline
\end{tabular}

In the larger study, the purpose of the interviews with the teachers was to ascertain the factors that obstruct quality teaching, what knowledge and skills the learners needed to be prepared for university, and which school interventions were in place to support the learners. The purpose of the interviews with lecturers was to establish the challenges they experience with first-year students' readiness in terms of school pedagogical requirements, subject knowledge requirements, the teachers' knowledge of university requirements, and the university interventions (if any) that were in place to support the students. Only the questions and responses that pertain to the learners' readiness are reported on here and analysed in the next section.

\section{Results}

Two questions were posed to the teachers in the semi-structured interviews. These were:

- Do you think that the school adequately prepares learners for university studies?

- What type of challenges and problems are learners experiencing in your subject in Grades 10 to12? 
Three questions were asked of the lecturers in the semi-structured interviews. The first question asked was if they thought that the schools were preparing the business education learners for a business degree at university. The second question had seven sub-points. The question was: In your opinion, are learners coming to university studies with the following skills:

- Time management and identification of priorities;

- Independent working;

- Problem-solving;

- Logical and conceptual work, structuring arguments;

- Communication, in particular, sustained writing and report writing;

- Reading, note-taking, and listening; and

- Some aspects of social and interpersonal skills?

The third question asked the lecturers to make suggestions about what the schools and teachers could do to prepare learners for university study.

The responses from the six educators and six academics to the above questions were analysed with Atlas.Ti analysis. A deductive thematic process was followed to analyse the responses since we used the characteristics of the first three dimensions of Lemmens's readiness and retention model as described above to identify the main themes and sub-themes (see Creswell \& Creswell, 2018). The themes were:

- Lecturers' and teachers' perceptions of university readiness;

- Language differentiation;

- A lack of critical thinking and problem-solving skills;

- Workload and time management; and

- Social problems.

The findings are described below.

\section{Lecturers' and teachers' perception of university readiness}

This theme resonates with Lemmens's (2010) notion of cognitive sub-dimension (skills and abilities, and academic preparedness). One sub-theme was identified from the responses that indicated that public schools are preparing learners in business education studies for higher education studies, and those that did not agree. There was a mismatch between lecturer and teacher perception of student university readiness. Irrespective of the years that the teachers had been teaching, the three from the Quintile 1 school believe that their school was preparing learners adequately for university. Two reasons were that "learners get a good foundation which is very useful at university" (MJ), and "the level of education in schools and the teacher involvement and dedication are assisting learners to compete well" (TK), while $\mathrm{AB}$ stated that the subject knowledge of economics lays a good foundation to pursue this subject at tertiary level. He said, "[F]rom Grade 10 learners are required to do markets, which is the same as the university stuff." 
In contrast with these remarks, two teachers (AH and NS) from the Quintile 4 school did not agree with their Quintile 1 counterparts that the school had prepared learners adequately for university studies. Their arguments were that "most learners struggle to work independently at university level" (AH) and that "the curriculum is designed for ideal circumstances and we are sitting with overcrowded classes, so it makes it difficult to adhere to time" (NS). The third teacher, MN, did not have a definite opinion about learners' readiness for university and said, "The schools do try, but not all the learners have the resources to develop their skills."

A similar trend in the responses from the lecturers was noted. The three lecturers from the traditional university indicated that the school curriculum did not adequately prepare the learners for higher education irrespective of the number of years' lecturing experience they had. In contrast, two of the three lecturers from the university of technology thought that the students were, at least to a certain extent, prepared for post-school studies. They were of the opinion that learners coming from well-functioning schools are better prepared for university. VG stated,

It is not only the school curriculum, they have social capital, and there are other aspects that contribute to them being university ready. It is not the school curriculum, per se, it is also the type of school and teachers, all the schools have the same curriculum. Certain schools do prepare the students well, but that is the minority.

LB put particular emphasis on the discrepancies between the university and school pass requirements and raised this as a serious concern. She explained,

Learners are allowed to 'pass' with less than 50\%, which means that some students have passed the school subject but have 'gaps' in their subject knowledge, which do cause concerns at university level.

Furthermore, the responses from the lecturers from the traditional university related more to the subject knowledge of first-year students. MM, who also said, "No, the learners were not adequately prepared for university study," explained that there were "gaps which the university identified, and, as a result, the university has support modules to help the students overcome the challenges in terms of language and mathematics." She articulated the concern she felt after the first assessment she gave to the first-year economic students.

The student outcomes of the first class test [showed that] the students with no economics background did better than students [who] had economics at Grade 12 level. It is about the assessment types at school level, such as define, and match words, and fill in [missing] words, and writing the [misnamed] 'essays.' We found these assessment methods to be counter intuitive as students then grapple with providing more depth in answering questions (those that go beyond merely defining) at first year [level]. 
$\mathrm{BW}$, who lectures accounting, shared a similar view as did MM and felt that learners are taught at a superficial level and lack critical thinking skills which are a major requirement of her subject. She stated,

My opinion is that schools focus on the application of accounting. In the first year of the accounting module, concepts and principles are taught, followed by the application of these principles. At school level I feel that teachers tend to focus on the application only and the learners become robotic, because they know how to do it, but not why.

While NH had mixed responses about how taking the business education subjects prepare learners for the B.Com. degree, she said,

To an extent yes, [school] does prepare learners who did business studies, economics, or some business management related subjects in high school, because the learners have a basic knowledge and understanding of business principles. To a lesser extent, no, because the students are not well equipped to discuss concepts and apply them in different scenarios. Analytical skills are lacking.

We found that while teachers and lecturers could provide detailed explanations of the challenges they face teaching their subject, not all of them could provide input regarding the strategies they or the university or school could implement to overcome these challenges. In addition, the results also revealed that both lecturers and teachers could give recommendations about which strategies could be employed but revealed none of their own intervention strategies.

\section{Language differentiation}

This theme falls under Lemmens's (2010) cognitive sub-dimension (skills and abilities, and academic preparedness). The teachers from the Quintile 1 school reported that a large percentage of learners (more than 90\%) at the school speak IsiXhosa as a home language, which is different from the language of instruction (English). In contrast, in the Quintile 4 school, where the languages of instruction are Afrikaans and English, the teachers reported that the percentage of learners whose language is different from the language of instruction, was $10 \%$ and below.

As is generally known, when English is a second or additional language, one of the major learning challenges for the learners is communication and understanding. According to $\mathrm{NH}$, writing essays or discussing a topic is a challenge for students. LB explained that students struggle with writing down sentences and/or documenting their thoughts. WD asserted that "students have to intellectually go through the process of understanding, translating, and retranslating into their native language." WD added,

Note-taking is a skill cultivated by understanding what is important vs. supplementary information. In addition, speed in noting and listening is, as a consequence, also affected negatively. 
It is clear that being second language or additional language speakers of English is one reason why learners are not adequately prepared for higher education studies.

\section{A lack of critical thinking and problem-solving skills}

This theme also falls under Lemmens's (2010) cognitive sub-dimension (skills and abilities, and academic preparedness). One of the teachers, $\mathrm{MN}$, was of the opinion that learners struggled with reading and writing. She also said, "The learners struggle with questions that test insight." She suggested that the curriculum content must be reduced "so that there can be more time for the development of skills."

According to LB, many students struggle with critical thinking. Her perception is that students are scared of thinking since it appears that they have been conditioned into believing that it is safe to do rote learning. They have been told, "You will pass when you memorise the textbook." This leads to students not being able to think critically and prevents them from developing problem-solving skills. WD also shared a sentiment around the problem-solving skills of students. She said,

Students can solve problems once they get going but they struggle with the initial assessment of the task, clarity of instructions and where to access information, as well as how to package the solution.

The answers from both the teachers and the lecturers indicated that the students could not think critically and analytically, and, as a result, they did not develop the problem-solving skills that are needed for university studies.

\section{Workload and time management}

Similar to the previous two themes, this theme also falls under Lemmens's (2010) cognitive sub-dimension. Two lecturers from the university explained that students struggled at university level to come to grips with the workload and to manage their time, mainly because there is no enforcement at university level in respect of study activities. NS felt that the volume of work and the time constraints, with no time for consolidation, hinder success in her subject. WD was of opinion that a lack of time management skills is one of the most noteworthy reasons most first-year students fail. She explained,

Students need social orientation for various reasons but also need to get a grip with the volume of reading required for university, note-taking, how to manage their academic week whilst still maintaining a balance with healthy exercise, eating, and social life.

All six teachers agreed that time management and the ability to work under pressure should be nurtured at high school so that students would be ready for a heavier workload at university level and could succeed. 


\section{Social problems}

A social problem was the last theme identified in the teachers' and lecturers' responses as a possible reason why some of the learners did not succeed at post-school studies. This theme recalls Lemmens's (2010) contextual dimension (parental, socio-cultural and financial). Both teachers and lecturers spoke about the socio-economic challenges that learners faced such as peer pressure, and drug and substance abuse, and a lack of parental involvement. Learners and students who come from different provinces must cope on their own (without the support base of home). MJ highlighted that "peer pressure and drug and substance abuse" is rife in his school. AB was particularly concerned about learners' lack of self-motivation and the lack of parental involvement in the community. She asserted,

Learners are not motivated and [are] uncertain about future career plans. Additionally, this causes a lack of focus. Parent's lack of involvement and social challenges at home and within the community also affect the learners' ability to perform to their best potential.

VG pointed out that students who come from other provinces and are compelled to find their own residences are particularly affected by social problems and made suggestions on how to assist these students.

First year is fraught with social and interpersonal problems, especially when students also come from another city and struggle to find residence. However, with assimilation into a group of ethical hard-working students, the student can acquire good social and interpersonal skills and feel supported. It is not only about the cognitive ability, but also to be socially, ethically, and environmentally aware.

All three teachers from the Quintile 1 School explained that for learners to overcome their learning challenges, they must be encouraged to improve, be positive and do well, and be involved in school activities.

Last, the lecturers explained in detail what the universities are doing to bridge the gap of a lack of foundational knowledge and skills for first-year students. They reported that both universities have support modules for first-year students, e-learning courses that consist of a range of videos to catch up with topics missed that students could revisit as many times as they want when they have identified gaps in their knowledge. They also provide online tutorials that are completed after every topic and said that mentoring sessions are available for at-risk students.

\section{Discussion}

The first finding from the responses of the teachers and the lecturers to the first question posed, indicates that there was agreement among all three teachers from the Quintile 1 School and the two academics from the University of Technology concerning the learners' readiness for post-school studies. They reported that the school was preparing the learners for higher 
education studies. Similarly, there was an agreement among two teachers from the Quintile 4 school and the three lecturers from the traditional university that the school did not prepare the learners adequately for higher education studies. Quintile 1 schools are not fee paying schools because most of the learners who are from African and coloured communities come from townships and low socio-economic backgrounds. These are also the schools that have larger class sizes, insufficient resources, and ill-developed infrastructures, with semi-skilled and less qualified educators (Department of Basic Education, 2016(b).) Quintile 4 schools, however, are categorised as fee paying schools, are in areas that are more affluent, are well resourced, and have more qualified and skilled educators. In addition, the most recent report released by the Department of Basic Education (2019) showed that the pass rate in Quintile 1 schools is significantly lower than in Quintile 4 schools, which is understandable given the schools' contextual dimensions (Lemmens, 2010).

There is also a cognitive difference between the traditional universities and universities of technology as well as a difference of focus. The traditional universities are more theorydriven as opposed to the universities of technology, which are more practically oriented (Department of Education, 1998). Additionally, the admission requirements of the traditional universities are generally more stringent than those of the universities of technology. It is then not surprising that the lecturers from the traditional university felt that public schooling was not adequately preparing the students for university study, and that two of the teachers from the Quintile 4 school agreed.

The findings also indicated that the Quintile 1 school's learners had overwhelmingly higher percentage of second and additional language speakers of English as opposed to the Quintile 4 school. This means that Quintile 1 learners are in a more disadvantaged position given that the medium of instruction and assessment is not their mother tongue. Quintile 4 learners have an advantage because they were taught and assessed in their home language (English and Afrikaans).

These two factors provide evidence for the lecturers' claim that the learners were not adequately prepared for university study; they came with a lack of subject knowledge and an inability to apply critical and analytical thinking that would have enabled them to understand how to solve problems in accounting 1 or economics, for example. Moreover, the students do not learn and do not construct new knowledge in their first language, so this is an additional challenge. The difficulty of having to learn in a different language relates directly to Lemmens's cognitive sub-dimension in that this will hinder their ability to think critically and analytically. Given the statistics presented above and the literature reviewed, we infer that the high failure and dropout rates of African and coloured students result from a lack of subject knowledge, the inability to apply critical and analytical thinking, and the fact that many students are second or additional language speakers of English. These characteristics of South African students reflect Lemmens's examples in his readiness and retention model as identified and discussed above.

Another significant finding agreed upon by most teachers is that time management skills should be nurtured at high school. However, one teacher felt that the current curriculum 
constraints put pressure on both teachers and learners to manage their time effectively. Goetze (2016), who is of the view that CAPS is disadvantaging learners because learners are continually overwhelmed with too much content and can therefore not cope with the workload, has also highlighted this point. Given the continual pressure placed on teachers to complete the curriculum, learners are not given sufficient opportunities to complete activities independently in the classroom, nor to collaborate with their peers.

The findings also revealed that the learners who participated in this study (particularly from the Quintile 1 school) are from disadvantaged communities as are most of the students registered at the universities whose lecturers participated in this study. Both teachers and lecturers were of the opinion that students and learners experience socio-economic challenges such as substance abuse by learners and lack of parental involvement. As Lemmens has pointed out in his readiness and retention model, without parental involvement and financial stability, learners' chances of success at higher education studies are slim; the statistics provided in the introductory section of this paper bear witness to this. These factors contribute to the complexity of providing higher education in South Africa (Department of Higher Education and Training, 2016, Council on Higher Education, 2016). The issues discussed in this paper provide evidence for Morrow's (2009) argument that students in general, and African and coloured students in particular, need academic support and an enabling learning environment if they are to complete their degree programmes successfully.

\section{Conclusion and recommendations}

The results of the study show that universities and schools are not working together to solve the ongoing challenges first-year business degree students face at university. The agreement among four of the six lecturers and two teachers that the public schooling system does not sufficiently prepare business education learners for university study should be a cause of great concern for all stakeholders involved in basic and higher education. What should be taken into consideration is that the study of business education at school gives learners the opportunity to enrol for a business degree at a university. This means that schools and business faculties should join forces and work collaboratively so that learners can be prepared adequately for higher education studies.

The findings discussed in this paper provide evidence that some teachers do not have a clear understanding of the requirements of learners if they are to gain access to university, and more importantly, what role the school curriculum should play to prepare them for higher education. It would appear that lecturers have little or no knowledge of the school curriculum and the different quintiles from which they come. Of particular concern is that lecturers in this study indicated that they and their universities are not taking any initiative to work closely with schools or the Department of Basic Education to help mitigate the school-based challenges they mentioned first-year students are experiencing. There was also no evidence that teachers are working with universities. 
One of the findings of this study reveals that the challenges students face can be traced back to the foundation phase in the public schooling system. Second language English learners, in particular, are bearing the brunt of the current system in that the medium of instruction in the foundation phase (Grade R to Grade 3) is their mother tongue, but from Grade 4 to Grade 12 all learners have no choice but to be instructed in Afrikaans or English. Another current major challenge (and this is mentioned in the literature) is the learners' lack of numeracy skills. This, along with a deficit of linguistic (or communicative) competence presents a serious obstacle to teachers, in the FET phase, in particular, and to university lecturers. These challenges should be enough to encourage business education teachers and lecturers to initiate a community of practice to take appropriate action. We argue that there are numerous mechanisms that could be put in place and strategies that could be implemented to prepare learners to pursue a business degree successfully at university

To establish a community of practice, it is imperative that the business faculty leadership take the initiative to establish a platform to ensure ongoing communication with business education teachers and curriculum advisers. We recommend that they meet with these stakeholders in their particular regions to identify current intervention strategies that are already being implemented at both schools and universities to equip the learners with the knowledge and skills needed. We argue that this information could assist them to collaborate to improve the current strategies and to develop new ones. Given that lecturers are expected to conduct research in their respective disciplines, this form of collaboration could provide the opportunity to assess the success of current intervention strategies and, given this information, predict the likely success of planned ones. More importantly, their research could also assist in developing a university readiness model for first-year business degree students.

Another recommendation is to equip lecturers with information about the current school business education curriculum. They need to understand the significance of different schools in terms of their quintile ranking and what it means for learners to attend a Quintile 1 school as opposed to attending a Quintile 5 school. This information would allow lecturers to understand better the different contexts of their first-year students. Working closely with business education teachers and the FET Curriculum Advisors, lecturers could help develop strategies that will aid learners' critical and analytical thinking skills.

Our final recommendation is that the Department of Basic Education should involve higher education stakeholders in the decision-making processes of the development of a school curriculum that will prepare learners adequately for higher education studies in general, and business education studies in particular. The issues discussed in this paper illustrate that education in South Africa is indeed a multifaceted system that needs the dynamic involvement and cooperation of both school teachers and staff members of institutions of higher learning. Together, they can begin to address and solve the learning challenges of the future leaders of South Africa. 


\section{References}

Alcock, J., Cockcroft, S., \& Finn, F. (2008). Quantifying the advantage of secondary mathematics study for accounting and finance graduates. Accounting and Finance, 48, 697-718.

Byrd, K. L., \& MacDonald, G. (2005). Defining college readiness from inside out: Firstgeneration college student perspectives. Community College Review, 33(1), 22-37.

Conley, D. T. (2007). Redefining college readiness. Eugene, ORE: Educational Policy Improvement Center.

Council on Higher Education. (2013). A proposal for undergraduate curriculum reform in South Africa: The case for a flexible curriculum structure. Pretoria, RSA: Council on Higher Education.

Council on Higher Education. (2016). South African higher education reviewed: Two decades of democracy. Pretoria, RSA: Council on Higher Education.

Creswell, J. W. (2014). Research design: Qualitative, quantitative and mixed methods approaches (4th ed.). Los Angeles, CA: SAGE.

Creswell, J. W., \& Creswell, J. D. (2018). Research design. Qualitative, quantitative \& mixed methods approaches (5th ed.). Los Angeles, CA: SAGE.

Department of Education. (1998). Green paper on further education and training. Preparing for the twenty-first century through education, training and work. Pretoria, RSA: Government Printer.

Department of Basic Education. (2016a). National Senior Certificate examination: National diagnostic report. Pretoria, RSA: Department of Basic Education.

Department of Basic Education. (2016b). Report on progress in the schooling sector against key learner performance and attainment indicators. Pretoria, RSA: Department of Basic Education.

Department of Basic Education. (2019). National Senior Certificate 2018 technical report: Results of the class of 2018. Pretoria, RSA: Department of Basic Education.

Department of Higher Education and Training. (2016). Annual monitoring report on the projected 2014 targets of the ministerial statement on student enrolment planning, 2014/15-2019/20. Pretoria, RSA: Department of Higher Education and Training.

Dos Reis, K. (2017). Teaching and learning report of the faculty of economic and management science (Unpublished report). Cape Town, RSA: University of the Western Cape. 
Dos Reis, K., \& Yu, D. (2018). Peer mentoring: Enhancing economics first years' academic performance. South African Journal of Higher Education, 32(6), 234-250.

Fisher, G., \& Scott, I. (2011). The role of higher education in closing the skills gap in South Africa. Cape Town, RSA: The World Bank Human Development Group.

Goetze, M. (2016). Five reasons why CAPS is harming our children. Retrieved from htpp://hookedonlearning.co.za

Henning, M., Hutter, I., \& Bailey, A. (2011). Qualitative research methods. London, UK: SAGE.

Leibowitz, B., van der Merwe, A., \& van Schalkwyk, S. (Eds.). (2009). Focus on first-year success: Perspectives emerging from South Africa and beyond. Stellenbosch, RSA: Sun Press.

Lemmens, J. C. (2010). Students' readiness for university education (Unpublished doctoral dissertation). University of Pretoria, Pretoria, RSA.

Letseka, M. (2014). The illusion of education in South Africa. Procedia: Social and Behavioral Sciences, 116, 4864-4869.

Lewin, T., \& Mawoyo, M. (2014). Student access and success: Issues and interventions in South African universities. Cape Town, RSA: The South African Institute for Advancement.

Maboya, M. J. (2017). Portfolio committee meeting: Progress on the implementation of the Curriculum and Assessment Policy Statement. Retrieved from http://pmg-assets.s3website-eu-west-1.amazonaws.com/170228CAPS_EVALUATION.pptx

Modisaotsile, B. M. (2012, March). The failing standard of basic education in South Africa (Policy Brief No. 72.) Retrieved from http://www.ai.org.za/wpcontent/uploads/downloads/2012/03/No.-72.The-Failing-Standard-of-BasicEducation-in-South-Africa1.pdf

Morrow, W. (2009). Bounds of democracy: Epistemological access in higher education. Pretoria, RSA: Human Sciences Research Council (HSRC) Press.

Nonjinge, G. (2018). If education is really a priority, we'll have to do things differently. Retrieved from https://www.news24.com/Columnists/GuestColumn/if-education-isreally-a-priority-well-have-to-do-things-differently-20180301

Papageorgiou, K., \& Halabi, A. K. (2014). Factors contributing toward student performance in a distance education accounting degree. Meditari Accounting Research, 22(2), 211-223. 
Rankin, M., Silvester, M., Vallely, M., \& Wyatt, A. (2003). An analysis of the implications of diversity for students' first level accounting performance. Accounting and Finance, $43,365-393$.

Rantsi, T. (2016). Tshikululu Social Investments NPC report to society 2016/2017 Retrieved from http://tshikululu.org.za/transitioning-from-secondary-school-to-tertiaryeducation-what-social-investors-should-know

Spaull, N. (2013). South Africa's education crisis: The quality of education in South Africa 1994-2011. Johannesburg, RSA: Centre for Development \& Enterprise.

Spaull, N., \& Kotze, J. (2015). Starting behind and staying behind in South Africa: The case of insurmountable learning deficits in mathematics. International Journal of Educational Development, 41, 12-24.

Statistics South Africa. (2019). Education series (Vol. V): Higher education and skills in South Africa, 2017 (Report 92-01-05). Pretoria, RSA: Statistics South Africa.

World Education News \& Reviews (WENR). (2017). Education in South Africa. Retrieved from https://wenr.wes.org/2017/05/education-south-africa 